\title{
Quality of Semi-Prepared Products from Rainbow Trout Waste (Onchorynchus mykiss) by Using Different Technological Strategics
}

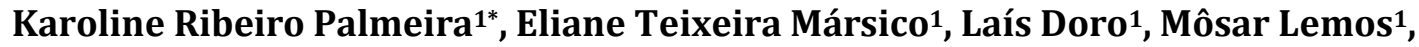 \\ Claudia Emília Teixeira1, Vania Margaret Flosi Paschoalin², \\ Maria Lúcia Guerra Monteiro', Carlos Adam Conte Júnior¹ \\ ${ }^{1}$ Department of Food Technology, Fluminense Federal University, Rio de Janeiro, Brazil \\ ${ }^{2}$ Department of Biochemistry, Chemistry Institute, Federal University of Riode Janeiro, \\ Rio de Janeiro, Brazil \\ Email: ${ }^{*}$.p.palmeira@globo.com, elianee@vm.uff.br, lah.doro@gmail.com, lemosmosar@hotmail.com \\ c.emilia@ibest.com.br, paschv@iq.ufri.br, marialuciaguerra@yahoo.com.br, mtaconte@vm.uff.br
}

Received 3 January 2014; revised 3 February 2014; accepted 10 February 2014

Copyright (C) 2014 by authors and Scientific Research Publishing Inc.

This work is licensed under the Creative Commons Attribution International License (CC BY). http://creativecommons.org/licenses/by/4.0/

(c) (i) Open Access

\section{Abstract}

The consumption of freshwater fish and fish products has gradually grown worldwide over the last decades, generating a proportional waste increase. The objective of the present study was to assess the chemical and bacteriological quality of restructured fish product, meatball-type, prepared with rainbow trout (Onchorynchus mykiss) waste added of $1 \%$ transglutaminase (MTG), 4\% textured soy protein (TSP) and replacing part of the sodium chloride with potassium chloride (75\%/25\%) as described below: T1-starch addition (control); T2-MTG addition (1\%); T3-soy protein addition (4\%); T4-soy protein addition (4\%) and MTG addition (1\%); T5-soy protein addition (4\%), MTG addition (1\%) and partial replacement of salt $(75 \% \mathrm{NaCl} / 25 \% \mathrm{KCl})$. Total aerobic mesophilic bacteria (TAMB), 2-thiobarbituric acid reactive substances (TBARS), pH determination and quantification of biogenic amines were performed on the day after manufacturing (P0) and after 60 days of storage $(\mathrm{P} 1)$ at $-25^{\circ} \mathrm{C} \pm 2^{\circ} \mathrm{C}$. The results showed that there was no significant difference $(\mathrm{p}<0.05)$ of microbiological quality, TBARS and $\mathrm{pH}$ after storage. $\mathrm{T} 4$ presented the lowest total biogenic amine content $(256.84 \mathrm{mg} / \mathrm{kg})$ whereas $\mathrm{T} 3$ and $\mathrm{T} 5 \mathrm{had}$ the highest value (791.36 and $707.19 \mathrm{mg} / \mathrm{kg}$, respectively) in this parameter. Putrescine was the biogenic amine that presented the highest concentration $(504.00 \mathrm{mg} / \mathrm{kg}$ ) in $\mathrm{T} 3$ and cadaverine that presented the smallest concentration $(0.36 \mathrm{mg} / \mathrm{kg})$ in $\mathrm{T} 4$. The use of technological strategies for developing new products with non-commercial fillets kept the most standards, having changes only in some biogenic amines.

\footnotetext{
"Corresponding author.
} 


\section{Keywords}

\section{Oncorhynchus mykiss; Soy Protein; Microbial Transglutaminase; Salt Replacer; Biogenic Amine}

\section{Introduction}

Freshwater fishes, such as rainbow trout, are among the foods considered of high nutritional value, excellent source of proteins with high nutritional value and digestibility around $90 \%$, besides calcium, unsaturated fatty acids (healthier) and vitamin B complex [1]. The average annual production of trout increased $18 \%$ in the last 10 years [2]. This growth was possible due to the increase in production scale and industrialization initiatives that favored trout marketing by large supermarket chains reaching markets in several metropolitan regions [3].

The fish industry, aiming at minimizing economic losses and environmental impact, has taken advantage of the less noble parts of certain food matrices to elaborate new products with added value [4]. The high production costs foster the study and the development of new technologies having in mind the use of all the animal parts to minimize waste and economic losses, and thus maximizing the companies' profit. This process includes the implementation of meat restructuring method on trimmings and low commercial value cuts to improve the appearance and texture of the new product, increasing its marketing value [5] [6].

Restructuring processes are technologically very important because the products obtained have high commercial value, low production cost, and are easy to use and marketing convenient. The use of transglutaminase (MTG) in the industrial preparation of these products has been widely studied, because its binding action does not depend on the use of sodium chloride or phosphates, generating healthier products because of lower levels of sodium salts [7]. Soy protein is an excellent source of essential amino acids, and has high digestibility, in addition some studies show that its consumption, is related to the reduction of non-infectious chronic diseases such as cardiovascular diseases, some types of cancer and osteoporosis [8]. However, due to high manipulation during the preparation of this product, the raw restructured must be kept frozen [9] [10]. Although scholars are conducting research focusing on the development of new products, there is no work reported in the literature that addresses the addition of MTG and soy protein associated with partial replacement of sodium chloride in fish products.

Numerous bacteriological and physicochemical methods have been developed for quality assessment of fish and fish products, but the most used are TBAR, TVB, TMA, hypoxanthine, and pH determinations and microbiologic analysis [11], as well as the quantification of biogenic amines which, besides being of fundamental imsportance for human health, are taken into consideration as quality assessment criteria [12].

The objective of the present study was to evaluate the storage effect on the bacteriological and chemical quality of meatballs prepared with Rainbow Trout (Oncorhynchus mykiss) waste according to 5 different treatments using transglutaminase (MTG), textured soy protein and partial replacement of sodium chloride by potassium chloride and stored frozen at $-25^{\circ} \mathrm{C} \pm 2^{\circ} \mathrm{C}$ for 60 days.

\section{Materials and Methods}

\subsection{Preparation of Rainbow Trout Meatballs}

The rainbow trouts (Oncorhynchus mykiss) were captured in tanks, and after removing the head were eviscerated and frozen. The restructured product was prepared with fillets of non-commercial size trouts which are treated as waste and were acquired at Morita Trout Farm, MG, Brazil. The base formulation was fillets, sugar, salt, garlic, onion, parsley and ascorbic acid. Five different treatments were made, with different contents of starch, soy protein and MTG, besides the partial replacement of sodium chloride by potassium chloride (Table 1). Starch was used when soy protein and MTG were not used. The frozen raw material was minced in a meat grinder using $3.0 \mathrm{~mm}$ disk and the ingredients and (dehydrated) seasonings were added in a technically important sequence (salt or $\mathrm{NaCl} / \mathrm{KCl}$ mixture, starch or TSP and/or MTG, seasonings, sugar and finally ascorbic acid) and mixed until forming a homogenous mass (Table 1). The fish meatballs were manually shaped, weighing approximately $30 \mathrm{~g}$ each, packed in expanded polystyrene trays and stored at approximately $-25^{\circ} \mathrm{C} \pm 2{ }^{\circ} \mathrm{C}$. The 
Table 1. Base formulation of the meatballs trout (g/100g).

\begin{tabular}{|c|c|c|c|c|c|}
\hline Ingredients & T1 & $\mathbf{T} 2$ & T3 & T4 & T5 \\
\hline Fillets & 91.5 & 94.5 & 91.5 & 90.5 & 90.5 \\
\hline Sugar & 0.2 & 0.2 & 0.2 & 0.2 & 0.2 \\
\hline Ascorbic acid & 0.2 & 0.2 & 0.2 & 0.2 & 0.2 \\
\hline Salt & 1.5 & 1.5 & 1.5 & 1.5 & 1.125 \\
\hline Garlic & 1.0 & 1.0 & 1.0 & 1.0 & 1.0 \\
\hline Soy Protein & --- & --- & 4.0 & 4.0 & 4.0 \\
\hline Onio & 1.0 & 1.0 & 1.0 & 1.0 & 1.0 \\
\hline Transglutaminase & --- & 1.0 & --- & 1.0 & 1.0 \\
\hline Chive & 0.6 & 0.6 & 0.6 & 0.6 & 0.6 \\
\hline Starch & 4.0 & --- & --- & --- & --- \\
\hline Potassium chloride & --- & --- & --- & --- & 0.375 \\
\hline
\end{tabular}

*Refers to the ingredients in $100 \mathrm{~g}$ of the final product. ${ }^{* *} \mathrm{~T} 1$ (starch addition), T2 (MTG addition), T3 (soy protein addition), T4 (soy protein and MTG addition) and T5 (soy protein addition, MTG addition and partial replacement of salt).

bacteriological and chemical quality assessments were performed in duplicate on the $1^{\text {st }}$ and $60^{\text {th }}$ days of storage. Samples were randomly collected from each treatment from the frozen meatballs, stored at $-25^{\circ} \mathrm{C} \pm 2^{\circ} \mathrm{C}$.

\subsection{Bacteriological Analysis}

Mediafor the count of total aerobic mesophilic bacteria (TAMB) was Plate Count Agar (PCA) and the plates were inverted to incubation at $35^{\circ} \mathrm{C} \pm 1^{\circ} \mathrm{C}$ during 48 hours [13].

\subsection{Chemical Quality}

The thiobarbituric acid reactive substances (TBARS) were determined by distilling the mixture of $\mathrm{HCl}$ and the sample added with distilled water, TBA was added to $25 \mathrm{~mL}$ of distilled and after immersion in a water bath and subsequent cooling, the reading was performed by the spectrophotometry $(538 \mathrm{~nm})$ described by [14] and adapted by [15]. The pH was determined in homogenized mixtures of meatballs and distilled water (1:10) [16], using a digital potentiometer (DIGIMED DM 22). Biogenic amines were quantified by High Performance Liquid Chromatography (HPLC) according to method described by [17]. The biogenic amines identified and quantified were: tyramine, putrescine, cadaverine, spermidine, histamine and spermine.

\subsection{Statistical Analysis}

One-way ANOVA followed by the Tukey Test was performed to compare average of each parameter evaluated for each treatment between days of storage. Data were analyzed using GraphPad Prism 5 program ${ }^{\circledR}$ (GraphPad Software, San Diego, California, USA) at a 95\% confidence level.

\section{Results and Discussion}

\subsection{Bacteriological Results}

There are no limits of TAMB in fish indicated by the brazilian legislation. However, the International Commission on Microbiological Specifications for Foods [18] recommends that the number of viable mesophilic bacteria does not exceed $10^{6} \mathrm{CFU} / \mathrm{g}$, because this count is considered critical in relation to the degree of product freshness. All the treatments presented counts below this limit and showed significant difference only in T1 after 60 days of storage, indicating that the meatballs were prepared under adequate sanitary conditions and that the storage maintained a controlled bacterial count. In the present study, all the values found in all the treatments were below $10^{5} \mathrm{CFU} / \mathrm{g}$, as shown in Table 2. In agreement with our findings [19] reported counts values rang- 
ing beteween in a period of 60 days storage at $-18^{\circ}$ in Rainbow Trout Kebab. [20] observed values below $10^{5}$ $\mathrm{CFU} / \mathrm{g}$ in fish burgers prepared with mechanically deboned meat (MDM) of Nile tilapia by using several binders and stored frozen. Through the bacteriological results, this study suggests the feasibility of using the rainbow trout in the preparation of meatballs

\subsection{Chemical Quality Results}

Table 3 summarizes the $\mathrm{pH}$ results of the 5 treatments which varied between 6.0 and 6.19 during the 60 -day storage, but no significant difference $(\mathrm{p}<0.05)$ was observed.

According to our results [21], observed a $\mathrm{pH}$ value of 6.55 in fish burger prepared with croaker waste. [22] studied Caranhas fish burger and found a mean $\mathrm{pH}$ value of 6.5 in fish burgers prepared with different salt contents. $\mathrm{pH}$ variation is related to storage conditions and the procedures to which the fish is submitted immediately after its capture, thus, this isolated value is not an exact criterion of meat freshness or quality, but must be interpreted in conjunction with other parameters [23] [24].

An increase in the $\mathrm{pH}$ value in food matrices may suggest loss of quality, indicating accumulation of basic metabolites such as ammonia and some organic bases produced by microbial and endogenous enzyme actions [24]-[26] mentions the use of cold as a food preservation method, because it slows the action of spoilage agents and decreases the chemical reactions. According to [27], the $\mathrm{pH}$ value for fresh fish meat is 6.0 - 6.5, which can increase during storage because of accumulation of metabolites such as amines, indicating a spoilage process.

All the treatments showed TBARS values (mg MDA $/ \mathrm{kg}$ ) below the limits indicated in literature as sensory perceptible (between 5 and $8 \mathrm{mg} \mathrm{MDA} / \mathrm{kg}$ ) [28]. The values found in the first day and after 60-day storage, independent of treatment, suggest that the combination of the antioxidant (ascorbic acid) action and storage at $-25^{\circ} \mathrm{C} \pm 2^{\circ} \mathrm{C}$ contributed to minimize the oxidation of the product. Another relevant factor is the average lipid content of this species of $4.95 \%$ described by [29], which classifies this species, according to [30] as lean fish $(<5 \%)$, with consequent low percent degradation of the lipid molecule. According to [31] freezing drastically reduces the lipid oxidation process, because it reduces the rate of enzyme activity. This fact was also pointed out by [32] on their study on hamburgers prepared with mechanically deboned meat (MDM), stored raw and frozen $\left(-20^{\circ} \mathrm{C}\right)$. Besides, these authors noted that the treatment with ascorbic acid reduced the lipid oxidation rate.

The limits acknowledged by the scientific literature for TBARS were used, observing that values above 1 - 2 mg of malondialdehyde/kg fish are associated to rancid taste and smell [31]. Moreover, [32] report that TBARS values above 1.59 of malondialdehyde/kg sample can cause harm to consumer's health, since malonic dialdehyde and other products of lipid oxidation have been related to the onset of cancer and therefore have called the attention of the scientific community. On the other hand, [33] stated that a product with values below 3.0 of malondialdehyde/kg should be considered in good condition.

Table 2. Count of aerobic mesophilic heterotrophic bacteria (UFC. $\mathrm{g}^{-1}$ ) of meatballs trout.

\begin{tabular}{cccccc}
\hline Days of storage & T1 & T2 & T3 & T4 & T5 \\
\hline P0 & $2.2 \times 10^{4 \mathrm{a}}$ & $2.5 \times 10^{4 \mathrm{a}}$ & $2.5 \times 10^{4 \mathrm{a}}$ & $5.3 \times 10^{4 \mathrm{a}}$ & $2.2 \times 10^{4 \mathrm{a}}$ \\
P1 & $3.5 \times 10^{2^{\mathrm{b}}}$ & $1.4 \times 10^{3^{\mathrm{a}}}$ & $2.7 \times 10^{3^{\mathrm{a}}}$ & $1.4 \times 10^{4 \mathrm{a}}$ & $4.6 \times 10^{3^{\mathrm{a}}}$ \\
\hline
\end{tabular}

${ }^{*}$ UFC. $\mathrm{g}^{-1}=$ colony forming units per gram of sample. ${ }^{* *}$ T1 (starch addition), T2 (MTG addition), T3 (soy protein addition), T4 (soy protein and MTG addition) and T5 (soy protein addition, MTG addition and partial replacement of salt). ${ }^{* * *} \mathrm{P} 0=$ day 1 , P1 = after 60 days of storage. Different letters in the same column indicate significant differences $(\mathrm{P}<0.05)$.

Table 3. Results of TBARS (mg MDA/kg) and pH analyzes of samples in different treatments of meatballs trout.

\begin{tabular}{ccccc}
\hline Parameters & T1 & T2 & T3 & T4 \\
\hline TBARS (P0) & $0.27^{\mathrm{a}} \pm 0.01$ & $0.12^{\mathrm{a}} \pm 0.04$ & $0.12^{\mathrm{a}} \pm 0.01$ & $0.12^{\mathrm{a}} \pm 0.01$ \\
TBARS (P1) & $0.60^{\mathrm{b}} \pm 0.08$ & $0.23^{\mathrm{a}} \pm 0.04$ & $0.17^{\mathrm{a}} \pm 0.03$ & $0.25^{\mathrm{a}} \pm 0.08$ \\
pH (P0) & $6.10^{\mathrm{a}} \pm 0.04$ & $6.10^{\mathrm{a}} \pm 0.02$ & $6.00^{\mathrm{a}} \pm 0.04$ & $0.10^{\mathrm{a}} \pm 0.02$ \\
pH (P1) & $6.17^{\mathrm{a}} \pm 0.01$ & $6.15^{\mathrm{a}} \pm 0.01$ & $6.08^{\mathrm{a}} \pm 0.03$ & $6.10^{\mathrm{a}} \pm 0.01$ \\
\hline
\end{tabular}

${ }^{*}$ T1 (starch addition), T2 (MTG addition), T3 (soy protein addition), T4 (soy protein and MTG addition) and T5 (soy protein addition, MTG addition and partial replacement of salt). ${ }^{* *}$ TBARS (thiobarbituric acid reactive substances) ${ }^{* *} \mathrm{P} 0=$ day $1, \mathrm{P} 1=$ after 60 days of storage. Different letters in the same line indicate significant differences $(\mathrm{P}<0.05)$. 
No difference $(\mathrm{P}<0.05)$ was observed among TBARS values (mg MDA $/ \mathrm{kg}$ ) during storage, except for T1 (control) which showed higher TBARS on the $60^{\text {th }}$ day in comparasion to first day of storage. This fact may be attributed to presence of substances such as ketones, amino acids, oxidized proteins, carbohydrates, pyridines, esters, sugars. These compounds as well as malonaldehyde, can react with thiobarbituric acid (TBA) directly influencing the TBARS result, allowing to suggest that the TBARS significant increase only in the control samples, may have been caused by the presence of starch and not necessarily by degradation of the lipid fraction [34]. Nevertheless, although has been observed an increase of TBARS in T1 the values of the analyzed samples were within the limits indicated in literature.

Figure 1 shows the values of biogenic mines obtained by HPLC. The tyramine concentration found in the different treatments was not considered high in $\mathrm{P} 0$, with the lowest value in $\mathrm{T} 5(3.47 \mathrm{mg} / \mathrm{kg})$ and the highest value in T1 (14.32 mg/kg). At the end of the 60-day storage (P1) tyramine concentration significantly $(\mathrm{P}<0.05)$ increased only in T1 and T2, where T2 reached the highest value (363.41 mg/kg). Tyramine is an important amine from the toxicological point of view because the detoxification mechanisms in humans may not be sufficient in case of high intake by allergic persons or patients that make use of drugs such as antidepressants and Parkinson disease symptom controllers [35]. The toxicity of tyramine and histamine are associated with the presence of alcohol and acetaldehyde, which can increase their toxic potential because they help to promote the transport of the biogenic amines to the intestinal wall [36]. According to [37] the toxic concentration of tyramine in healthy humans is $125 \mathrm{mg} / \mathrm{kg}$, while in immunocompromised persons this value falls to $6 \mathrm{mg} / \mathrm{Kg}$. Studies showed that in addition to its toxicity, tyramine promotes the adherence of pathogens such as Escherichia coli 0157:h7 on the gastric mucosa [38].

Histamine is considered the most important amine in fish [39] and the most toxic of the amines detected in food [40], but its toxic effects depend on concentration, the presence of other amines and the susceptibility of the individual, besides its health condition [41]. In the present study, the meatballs in treatments T1, T3 and T5 presented histamine levels of 106.15, 121.74 and $293.45 \mathrm{mg} / \mathrm{kg}$, respectively, exceeding the maximum limit of $50 \mathrm{mg} / \mathrm{kg}$ established by the [42]. However, the samples of treatments T2 $(23.24 \mathrm{mg} / \mathrm{kg})$ and T4 (14.38 mg/kg) presented levels below the recommended limit and only the meatballs in treatment $\mathrm{T} 5$ exceeded the histamine limit established by the European Community [43]. Besides, T5 was the only treatment that presented a significant histamine content increase $(\mathrm{P}<0.05)$ after 60 days of storage $(\mathrm{P} 1)$ when compared to the contents in P0.
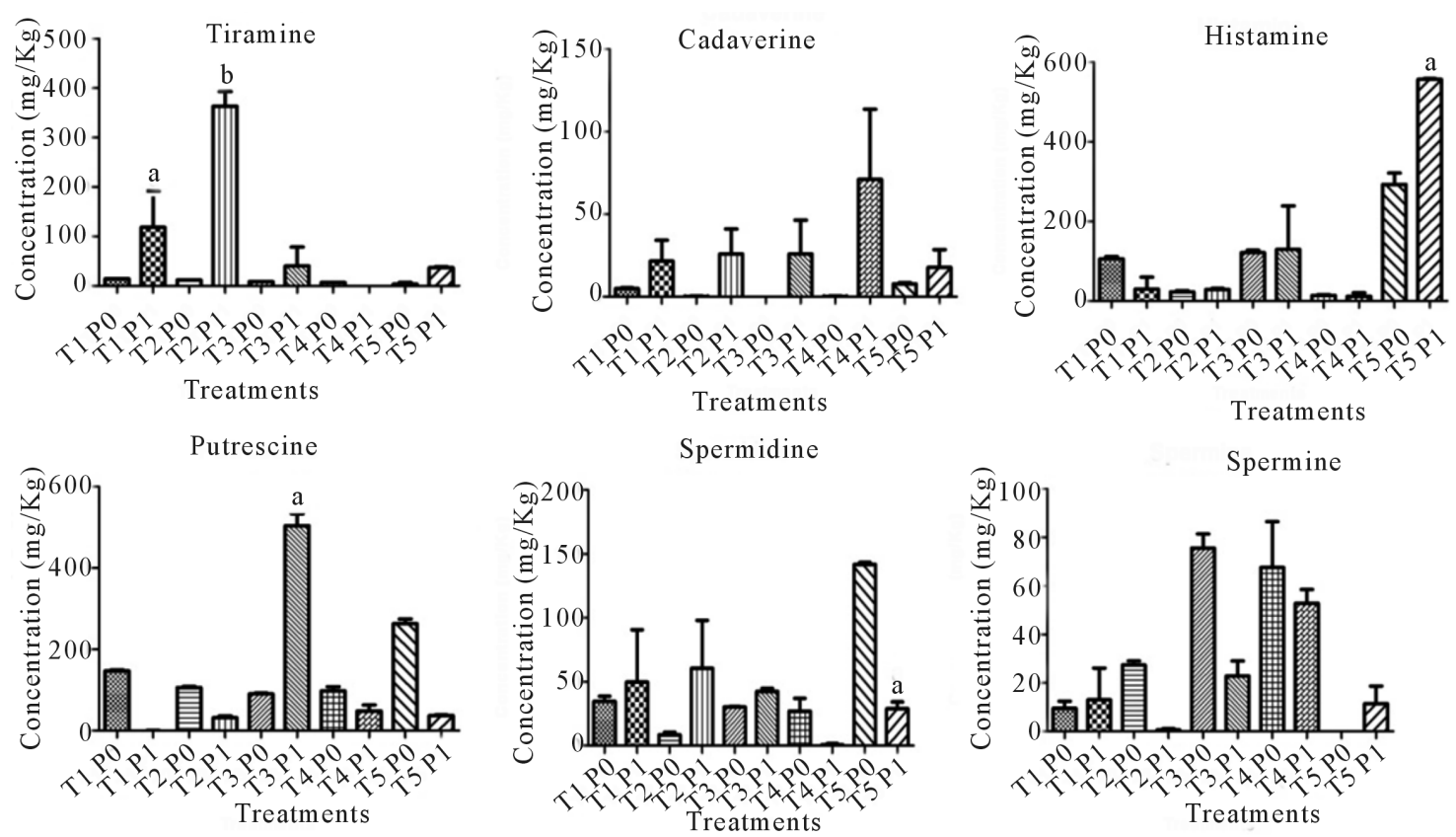

Figure 1. Values of biogenic amines in meatballs trout immediately after preparation (P0) and after 60 days of storage (P1). ${ }^{*}$ T1 (starch addition), T2 (MTG addition), T3 (soy protein addition), T4 (soy protein and MTG addition) and T5 (soy protein addition, MTG addition and partial replacement of salt). Different letters in the same graph indicate significant differences $(\mathrm{P}<0.05)$. 
There are no official limits for other biogenic amines, but the concentration of amines such as tyramine should be observed when associated with histamine, putrescine and cadaverine to evaluate the overall presence of biogenic amines in the food matrices the intake of which can lead to alterations of the organism [36].

Although the count of heterotrophic aerobic mesophilic bacteria have been constant during the study may have occurred decreased counts of specific bacterial groups and the development of other genres. Accordingly, bacteria that produce decarboxylases enzymes may have been favored by selective pressure, including lactic acid bacteria Tetragenococcus muriatics [44]-[46] and Citrobacter spp beyond that was isolated in Rainbow Trout [47] and fish derivatives frozen [48] [49]. Although there is no increase in the total bacterial load, the predominant bacterial groups of positive decarboxylase could explain the increase of histamine and tyramine during the storage.

Putrescine presented high values independent from treatment, with $\mathrm{T} 5$ showing the highest concentration ( $263.27 \mathrm{mg} / \mathrm{kg})$. When the samples were analyzed in P1, only T3 presented a significant increase $(\mathrm{P}<0.05)$. Arginine and proline are amino acids precursors of putrescine and are present in concentrations of 8 and $5.3 \%$ respectively in soy protein, a fact that can be associated with the significant increase of this biogenic amine in treatments with added soy protein [50].

On the other hand, cadaverine was the biogenic amine which kept the smallest levels both in P0 and P1. Cadaverine is mostly produced by spoilage bacteria that grow at high temperatures [51]. No significant difference was observed in any treatment after 60 -day storage at $-25^{\circ} \mathrm{C} \pm 2^{\circ} \mathrm{C}$ as well as on the mesophilic bacterial load was observed when P0 and P1 were compared (Figure 1). This behavior partially explains the absence of alteration of cadaverine levels. Despite the low levels found in the present study, cadaverine and putrescine are associated to the increase of histamine intestinal absorption, enhancing the toxicity of this amine, in addition to increasing the action of tyramine [52] [53]. These amines can also act as nitrosamine precursors originating carcinogenic compounds [26].

Spermine was found in low concentrations in all the treatments. The levels of this amine presented reduction in all treatments. The behavior of spermidine was similar, with its highest value in T5 $(141.69 \mathrm{mg} / \mathrm{kg})$ in P0 and presenting significant reduction after the 60-day storage period (P1). According to [54], due to their endogenous origin, the limits of spermine and spermidine tend to decrease or remain the same, during storage, and for this reason these amines are generally not associated with health hazardous effects when evaluated separately [55], and are usually associated to allergic processes [3].

According to [41] the presence of biogenic amines in food is doubly important, first because the intake of products with high concentration of biogenic amines may cause significant toxicological and physiological effects to human health and second, because they may be used as quality indicators in certain foods. These authors also mention that the food industry is interested in reducing their levels in fish, because in addition to being linked to health and quality standards, they cause consumer rejection. They also state that biogenic amines can be used as quality control indices, because they vary during food preparation and storage, starting with low concentrations in the fresh product and increasing during storage associated to bacterial growth.

When the biogenic amine overall concentration was analyzed it was observed that the T3 samples after 60 days of storage and T5, independent of the storage time, presented the highest values. Soy protein addition in those treatments (T3 and T5) seems to have influenced the presence of these amines. According to [56], the amines present in higher concentration in soybeans are putrescine, cadaverine, agmatine, spermine and spermidine, because arginine, lysine, proline and tyrosine amino acids which are the precursors of the above mentioned biogenic amines are present in the composition of the soy protein.

In addition, in $\mathrm{T} 5$ there was replacement of $25 \%$ sodium chloride by potassium chloride. According to [57] some ingredients and additives have been used to increase the technological properties and/or sensory attributes during production or in the final product, however in some cases they can also act as inhibitors of bacterial growth, which is one of the conditions to form biogenic amines. The author also mentions that ingredients such as salt $(\mathrm{NaCl})$ reduce the bacterial growth that interferes in the endogenous and exogenous proteolytic enzyme activity, inhibiting the formation of free amino acids and consequently reducing the formation of biogenic amines. In this manner, it seems that the replacement of $25 \%$ sodium chloride by potassium chloride may have influenced the overall amine values in $\mathrm{T} 5$.

\section{Conclusions}

The addition of transglutaminase (MTG), textured soy protein (TSP) and partial replacement of sodium chloride 
by potassium chloride in the product caused no significant changes during the period of storage in most parameters evaluated, only in some biogenic amines.

The biogenic amines proved to be a promising quality indicator in the studied products, mainly in those treatments with soy protein addition, and should be carefully evaluated in products prepared with fish waste and salt substitutes, because despite its health appeal, the technological effect of this ingredient may be compromised.

The present study suggests that the combined use of these ingredients associated to frozen storage can be applied as alternative for elaboration of new semi-prepared products manufactured from trout wastes leading advantages in the fish industry.

\section{Acknowledgements}

The authors are thankful for the financial support of the State of Rio de Janeiro Carlos Chagas Filho Research Foundation (FAPERJ), process number E-26/103.003/2012. K. R. Palmeira was supported by the National Council for Scientific and Technological Development (CNPq) and Coordination for the Improvement of Higher Education Personnel (CAPES).

\section{References}

[1] Contreras-Guzmán, E.S. (2002) Bioquímica de Pescados e Invertebrados. CECTA-USACH Santiago, 309 p.

[2] FAO (2008) Pesca e Departamento da Aquicultura: O Estado Mundial da Pesca e da Aquicultura.

[3] Kalac, P. and Krausova, P. (2005) A Review of Dietary Polyamines: Formation, Implications of Growth and Health and Occurrence in Foods. Food Chemistry, 90, 219-230. http://dx.doi.org/10.1016/j.foodchem.2004.03.044

[4] Monteiro, M.L.G., Mársico E.T., Teixeira C.E., Mano S.B., Conte Junior, C.A. and Vital, H.C. (2012) Validade Comercial de Filés de Tilápia do Nilo (Oreochromisniloticus) Resfriados Embalados em Atmosfera Modificada e Irradiados. Ciência Rural, 42, 737-743. http://dx.doi.org/10.1590/S0103-84782012000400027

[5] Castro-Briones, M., Calderón, G.N., Velzquez, G., Rubio, M.S., Vázquez, M. and Ramírez, J.A. (2009) Mechanical and Functional Properties of Beef Products Obtained Using Microbial Transglutaminase with Treatments of PreHeating Followed by Cold Binding. Meat Science, 83, 229-238. http://dx.doi.org/10.1016/j.meatsci.2009.05.002

[6] Torres, E. and Okani, E.T. (1997) Teste de TBA: Ranço em Alimentos. Revista Nacional da Carne, 248, 68-76.

[7] Ferreira, M.S., Mársico, E.T., Medeiros, R.J., Pombo, C.R., Freitas, M.Q., São Clemente, S.C. and Conte Junior, C.A. (2012) Comparação das Características Físico-Químicas e Sensoriais de Hambúrgueres de Carne Bovina Elaborados com Cloreto de Sódio, Polifosfato e Transglutaminase. Revista Brasileira de Medicina Veterinária, 34, 52-60.

[8] Silva, M.S., Naves, M.M.V., Oliveira, R.B. and Leite, O.S.M. (2006) Composição Química e Valor Protéico do Resíduo de soja em Relação ao Grão de Soja. Ciência e Tecnologia de Alimentos, 26, 571-576. http://dx.doi.org/10.1590/S0101-20612006000300014

[9] Márquez, E., Arévalo, E., Barboza, Y., Benítes, B., Rangel, L. and Archile, A. (2006) Efecto de la Concentración de Transglutaminasa y Tiempo de Reacción en la Estabilidad de Productos Reestructurados. Revista Cent, 16, 662-667.

[10] Ruiz-Capillas, C. and Moral, A. (2001) Correlation between Biochemical and Sensory Quality Indices in Hake Stored in Ice. Food Research International, 34, 441-447. http://dx.doi.org/10.1016/S0963-9969(00)00189-7

[11] Rodrigues, B.L., Álvares, T.S., Costa, M.P., Sampaio, G.S.L., De la Torre, C.A.L., Mársico, E.T. and Conte Júnior, C.A. (2013) Concentration of Biogenic Amines in Rainbow Trout (Oncorhynchus mykiss) Preserved in Ice and Its Relationship with Physicochemical Parameters of Quality. Aquaculture Research \& Development, 4, 1-4.

[12] Yokoyama, K., Nio, N. and Kikuchi, Y. (2004) Properties and Application of Microbial Transglutaminase. Applied Microbiology and Biotechnology, 64, 447-454. http://dx.doi.org/10.1007/s00253-003-1539-5

[13] APHA-American Public Health Association (2001) Compendium of Methods for the Microbiological Examination of Foods. Washington.

[14] Tarladgis, B., Watts, B.M. and Yonathan, M. (1960) Distillation Method for Determination of Malonaldehyde in Rancid Food. Journal of American Oil Chemistry Society, 37, 44-48. http://dx.doi.org/10.1007/BF02630824

[15] Monteiro, M.L.G., Mársico, E.T., Viriato, I.M., Souza, J.M.L. and Conte Junior, C.A. (2012) Preparation of Added Value Byproducts from the Waste Material of Tilapia (Oreochromis niloticus) Processing. Journal of Aquaculture Research \& Development, 3, 1-5. http://dx.doi.org/10.4172/2155-9546.1000150

[16] Conte Junior, C.A., Peixoto, B.T.M., Lopes, M.M., Franco, R.M., Freitas, M.Q., Fernández, M. and Mano, S.B. (2010) Effect of Modified Atmosphere Packaging on the Growth/Survival of Yersinia enterocolitica and Natural Flora on 
Fresh Poultry Sausage. In: Méndez Vilas, A., Eds., Current Research, Technology and Education Topics in Applied Microbiology and Microbial Biotechnology, Badajoz, 1217-1223.

[17] Lázaro de la Torre, C.A., Conte Junior, C.A., Cunha, F.L., Mársico, E.T., Mano, S.B. and Franco, R.M. (2013) Validation of an HPLC Methodology for the Identification and Quantification of Biogenic Amines in Chicken Meat. Food Analytical Methods, 6, 1-8.

[18] ICMSF (2002) Microrganisms in Foods 7.Microbiological Testing in Food Safety Management. Kluwer Academic/ Plenum Publishers, New York.

[19] Simsek, A. and Killic, B. (2013) Effects of Marination, Cooking and Storage on Physico-Chemical and Microbiological Properties of Ready to Eat Trout Döner Kebab. Journal für Verbraucherschutz und Lebensmittelsicherheit, 8, 165174. http://dx.doi.org/10.1007/s00003-013-0825-0

[20] Marengoni, N.G., Pozza, M.S.S., Braga, G.C., Lazzeri, D.B., Castilha, L.D., Bueno, G.W., Pasquetti, T.J. and Polese, C. (2009) Caracterização Microbiológica, Sensorial e Centesimal de fishburgers de Carne de Tilápia Mecanicamente Separada. Revista Brasileira de Saúde e Produção Animal, 10, 168-176.

[21] Silva, S.R. and Fernandes, E.C.S. (2010) Aproveitamento da Corvina (Argyrosomus regius) para Elaboração do Fishburger. Caderno Pesqueiro, 17, 67-70.

[22] Sales, P.V.G., De Cól, C.D. and Souza, F.G. (2012) Avaliação da Qualidade do Fishburger de Caranha. Enciclopédia Biosfera, 8, 259-264.

[23] Moura, A.P., Mayer, M., Landgraf, A.M. and Tenuta, F. (2003) Qualidade Química e Microbiológica do CamarãoRosa Comercializada em São Paulo. Brazilian Journal of Pharmaceutical Sciences, 39, 5-9.

[24] Rodrigues, B.L., Santos, L.R., Mársico, E.T., Camarinha, C.C., Mano, S.B. and Conte Junior, C.A. (2012) Qualidade Físico-química do Pescado Utilizado na Elaboração de Sushis e Sashimis de Atum e Salmão Comercializados no Município do Rio de Janeiro, Brasil. Semina: Ciências Agrárias, 33, 1849-1856.

[25] Okeyo, G.O., Lokuruka, M.N. and Matofari, J.W. (2009) Nutritional Composition and Shelf Life for the Lake Vitoria Nile Perch (Latesniloticus) Stored in Ice. African Journal of Food, Agriculture, Nutrition and Development, 9, 1-6.

[26] Jay, J.M. (2005) Microbiologia de Alimentos. Artmed.

[27] Kyrana, V.R., Lougovois, V.P. and Valsamis, D.S. (1997) Assessment of Shelf-Life of Maricultured Gilthead Sea Bream (Sparusaurata) Stored in ice. International Journal of Food Science Technology, 32, 339-347. http://dx.doi.org/10.1046/j.1365-2621.1997.00408.x

[28] Osawa, C.C., Felício, P.E. and Gonçalves, L.A.G. (2005) Teste de TBA Aplicado a Carnes e Derivados: Métodos Tradicionais, Modificados e Alternativos. Revista Química Nova, 28, 655. http://dx.doi.org/10.1590/S0100-40422005000400019

[29] Rasmussen, R.S. and Ostenfeld, T.H. (2000) Effect of Growth Rate on Quality Traits and Feed Utilization of Rainbow Trout (Oncorhyncus mykiss) and Brook Trout (Salvelinus fontinalis). Aquaculture, 184, 327-337. http://dx.doi.org/10.1016/S0044-8486(99)00324-5

[30] Silva, J.J. and Chamul, R.S. (2000) Composition of Marine and Freshwater Finfish and Shellfish Species and Their Products. In: Marine and Freshwater Products Handbook, Technomic Publishing Company, Inc., 31-46.

[31] Colla, L.M. and Prentice-Hernandez, C. (2003) Congelamento e Descongelamento—Sua Influencia Sobre os Alimentos.Vetor-Revista de Ciências Exatas e Engenharias, 13, 53-66.

[32] Ozer, O. and Sariçoban, C. (2010) The Effects of Butylated Hydroxyanisole, Ascorbic Acid, and $\alpha$-Tocopherol on Some Quality Characteristics of Mechanically Deboned Chicken Patty during Freezer Storage. Czech Journal of Food Sciences, 28, 150-160.

[33] Al-Kahtani, H.A., Abu-Tarboush, H.M., Bajaber, A.S., Atia, M., Abou-Arab, A.A. and El-Mojaddidi, M.A. (1996) Chemical Changes After Irradiation and Post-Irradiation Storage in Tilapia and Spanish Mackerel. Journal of Food Science, 61, 729-733. http://dx.doi.org/10.1111/j.1365-2621.1996.tb12191.x

[34] Shetty, K., Paliyath, G., Pometto, A. and Levin, R.E. (2006) Food Biotechnology. CRC Press (Taylor \& Francis), Boca Raton.

[35] Silla-Santos, M.H. (1996) Biogenic Amines: Their Importance in Foods. International Journal of Food Microbiology, 29, 213-231.

[36] Ruiz-Capillas, C., Herrero, A.M. and Jimenez-Colmenero, F. (2011) Reduction of Biogenic Amine Levels in Meat and Meat Products. In: Rai, M. and Chikindas, M., Eds., Natural Antimicrobial in Food Safety and Quality, 154-166.

[37] McCabe, B.J. (1986) Dietary Tyramine and Other Precursors Amines in MAOI Regimens: A Review. Journal of the American Dietetic Association, 86, 1059-1064.

[38] Lyte, M. (2004) The Biogenic Aine Tyramine Modulates the Adherente of Escherichia coli O157:O7 to Intestinal Mucosa. Journal of Food Protection, 6, 878-883. 
[39] Teodoro, J.C. (2008) Influência das Condições de Alimentação de Glicerol e Ornitina na Produção de Ácido Clavulânico por Streptomyces clavuligerus. Tese de Doutorado, Universidade Federal de São Carlos, São Carlos (SP).

[40] Izquierdo, P., Allara, M., Torres, G., Sánchez, M., Peña, G. and Sangronis, M. (2004) Aminas Biógenas y Crecimiento Bacteriano en Carne de Hamburguesas. Revista Científica, 14, 7-12.

[41] Sattler, J., Hafner, D. and Klotter, H.J. (1988) Food-Induced Histaminosis as an Epidemiological Problem: Plasma Histamine Elevation and Haemodynamic Alterations after Oral Histamine Administration and Blockade of Diamine Oxidase (DAO). Agents and Actions, 23, 361-365. http://dx.doi.org/10.1007/BF02142588

[42] Önal, A. (2007) A Review: Current Analytical Methods for the Determination of Biogenic Amines in Foods. Food Chemistry, 103, 1475-1486. http://dx.doi.org/10.1016/j.foodchem.2006.08.028

[43] C.E. (Comunidade Européia) (2005) Relativo à Critérios Microbiológicos Aplicáveis Aos Gêneros Alimentícios. Jornal Oficial da União Européia, 338.

[44] Gardini, F., Martuscelli, M., Caruso, M.C., Galgano, F., Crudele, M.A., Favati, F., Guerzoni, M.E. and Suzzi, G. (2001) Effects of $\mathrm{pH}$, Temperature and $\mathrm{NaCl}$ Concentration on the Growth Kinetics, Proteolytic Activity and Biogenic Amine Production of Enterococcus faecalis. International Journal of Food Microbiology, 64, 105-117. http://dx.doi.org/10.1016/S0168-1605(00)00445-1

[45] Giraffa, G. (2002) Enterococci from Foods. FEMS MicrobiologyReviews, 26, 163-171. http://dx.doi.org/10.1111/j.1574-6976.2002.tb00608.x

[46] Kuda, T., Mihara, T. and Yano, T. (2007) Detection of Histamine and Histamine-Related Bacteria in Fish-Nukazuke, a Salted and Fermented Fish with Rice-Bran, by Simple Colorimetric Microplate Assay. Food Control, 18, 677-681. http://dx.doi.org/10.1016/j.foodcont.2006.02.016

[47] Navarrete, P., Magne, F., Mardones, P., Riveros, M., Opazo, R., Suau, A., Pochart, P. and Romero, J. (2010) Molecular Analysis of Intestinal Microbiota of Rainbow Trout (Oncorhynchus mykiss). FEMS Microbiology Ecology, 71, 148156. http://dx.doi.org/10.1111/j.1574-6941.2009.00769.x

[48] Taylor, S.L. and Speckhard, M.W. (1983) Isolation of Histamine-Producing Bacteria from frozen Tuna. Marine Fisheries Review, 45, 4-6.

[49] Chen, H.C., Huang, Y.R., Hsu, H.H., Lin, C.S., Chen, W.C., Lin, C.M. and Tsai, Y.H. (2010) Determination of Histamine and Biogenic Amines in Fish Cubes (Tetrapturus angustirostris) Implicated in a Food-Borne Poisoning. Food Control, 21, 13-18. http://dx.doi.org/10.1016/j.foodcont.2009.03.014

[50] Ruiz-Capillas, C. and Moral, A. (2005) Free Amino Acids in Muscle of Norway Lobster (Nephrops novergicus (L.)) in Controlled and Modified Atmospheres during Chilled Storage. Food Chemistry, 86, 85-91. http://dx.doi.org/10.1016/j.foodchem.2003.08.019

[51] Brink, B., Ten, D., Joosten, H.M.L.J. and Huis, I.V. (1990) Occurrence and Formation of Biologically Active Amines in Foods. International Journal of Food Microbology, 11, 73-84. http://dx.doi.org/10.1016/0168-1605(90)90040-C

[52] Ruiz-Capillas, C. and Jiménez-Colmenero, F. (2004) Biogenic Amine Content in Spanish Retail Market Meat Products Treated with Protective Atmosphere and High Pressure. European Food Research and Technology, 218, $237-241$. http://dx.doi.org/10.1007/s00217-003-0848-3

[53] FDA (2001) Scombrotoxin (Histamine) Formation (A Chemical Hazard). Fish and Fisheries Products Hazards and Controls Guidance, 3rd Edition.

[54] Bardócz, S. (1995) Polyamines in Food and Their Consequences for Food Quality and Human Health. Trends in Food Sciences \& Technology, 6, 341-346. http://dx.doi.org/10.1016/S0924-2244(00)89169-4

[55] Hernández-Jover, T., Izquierdo-Pulido, M., Veciana-Nogués, M.T., Mariné-Font, A. and Viidal-Carou, M.C. (1997) Biogenic Amine and Polyamine Contents in Meat and Meat Products. Journal of Agriculture and Food Chemistry, 45, 2098-2102. http://dx.doi.org/10.1021/jf960790p

[56] Gloria, M.B.A. (2006) Bioactive Amines. Food Science and Technology, 149, 13.

[57] Virgili, R., Saccani, G., Gabba, L., Tanzi, E. and Soresi Bordini, C. (2007) Changes of Free Amino Acids and Biogenic Amines during Extended Ageing of Italian Dry-Cured Ham. LWT-Food Science and Technology, 40, 871-878. 


\section{List of Abbreviations}

$\mathrm{CFU}=$ colony forming units

$\mathrm{g}=$ gramme

$\mathrm{HCl}=$ hydrochloric acid

HPLC = High Performance Liquid Chromatography

$\mathrm{KCl}=$ potassium chloride

$\mathrm{Kg}=$ kilogram

MDA = malondialdehyde

MDM = mechanically deboned meat

MTG = transglutaminase

$\mathrm{NaCl}=$ sodium chloride

PCA = Plate Count Agar

TAMB $=$ Total aerobic mesophilic bacteria

TBARS $=$ 2-thiobarbituric acid reactive substances

TMA $=$ trimethylamine

TSP $=$ textured soy protein

$\mathrm{TVB}=$ total volatile bases 